\title{
Can biofertilization ameliorate green onion production under salinity stress?
}

\author{
Manal A. Abd Alla ${ }^{(1)}$, H. M. Abdel-Rahman ${ }^{(2)}$ and Hassan El-Ramady ${ }^{(3)}$ * \\ (1) Cross-pollinated Vegetables Dept., Sakha Sta. Hort. Inst., Agric. Res. Center, Egypt \\ (2) Microbiology, Botany Dept., Fac. of Agric., Benha Uni., Moshtohor, Kaliobya, Egypt \\ ${ }^{(3)}$ Soil and Water Dept., Fac. of Agric., Kafrelsheikh Uni., Kafr El-Sheikh, Egypt \\ *Corresponding author: Hassan El-ramady (ramady2000@gmail.com)
}

\begin{abstract}
In current study, two successive experiments were carried out during 2014 and 2015 at the Experimental Research Farm, Sakha Horticulture Station, Kafr El-Sheikh. Eleven treatments included combinations with N, P and $\mathrm{K}$ microbial inoculants and $1 / 3$ or $2 / 3$ or $100 \%$ of $\mathrm{N}$, P and K-mineral fertilizers. The effect of mineral combined with bio-fertilizers on quality and productivity of green onion under salt-affected soils has been investigated as well as on soil microbial enzyme activities. In general the highest values of soil dehydrogenase and alkaline phosphatase activities were 27.0 and $35.3 \mu \mathrm{g} \mathrm{TPF} \mathrm{g} \mathrm{g}^{-1} \mathrm{dw} \mathrm{h}^{-1}$ and 20.9 and $15.0 \mu \mathrm{g} \rho \mathrm{NP} \mathrm{g}^{-1} \mathrm{~h}^{-1}$, respectively in both seasons using of the combination of these fertilizers (NPK-biofertilizers combined with $100 \%$ NPK-mineral fertilizers). Concerning vegetative growth parameters and total yield, NPK-microbial inoculants combined with $100 \%$ NPK-mineral fertilizers had the highest values. There were not significant differences in the most cases between N-microbial inoculants combined with $100 \% \mathrm{NPK}$-mineral fertilizers and PK-microbial inoculants combined with $100 \%$ NPK-mineral fertilizers, comparing with 2/3 NPK-mineral fertilizers + NPK- microbial inoculants. Total chlorophyll content was reduced by using biofertilizers alone (NPK-microbial inoculants alone). Moreover, using biofertilizers led to relatively decrease soil salinity. The results of this study suggest that, it should be replaced the mineral fertilizers by biofertilizers, even partially, to produce a better food and such integrated nutrient management program should be addressed under salt-affected soils.
\end{abstract}

Key words: Green onion, biofertilizers, microbial inoculants, mineral fertilizers, total yield, quality, enzyme activities.

\section{Introduction}

Onion (Allium cepa L.) is one of the oldest bulb vegetables, which its bulb have been found in ancient Egypt (Brewster 2008). This crop belongs to the family Liliaceae and originated in the mountainous regions of Turkmenistan and north Iran (Brewster 2008; Baliyan and Baliyan 2013).

Regarding the global production of onion, it is estimated that, over 3.6 million hectare of onions are grown annually around the world and about 170 countries cultivate this crop for domestic use. Egyptian onion crop is famous all over the world due to its superior quality and early appearance in European markets as well as for its using for food and as a traditional medicine (Hussein et al. 2007).

Onion mainly is grown as food materials however it has medicinal properties and has been used for the treatment of various ailments such as skin diseases, ear pain, strokes and heart attack as well as antioxidant flavonoids (Pérez-Gregorio et al. 2014). It is a popular seasoning vegetable and its green leaves are rich in vitamins (A, C, E and K) as well as quercetin (Baliyan 2014). Green onion, as one of the leafy vegetables, is commercially produced in Egypt particularly for fresh consumption in certain occasions such as Sham El-Nessim
"Smelling the Breeze" (El Sheikha and Montet, 2015).

Currently, at least $20 \%$ of the world's irrigated land is salt-affected. Among those affected by salt, about $60 \%$ are sodic (Qadir et al. 2006). Furthermore, these soils could be classified into three groups (saline, sodic and saline-sodic soils) depending upon the nature and amount of soluble salts (Horneck et al. 2007). Several studies used various amendments to improve the physical, chemical and biological properties of saline sodic and sodic soils (Amer and El-Ramady 2015). It is reported that salt affected soils represent $30 \%$ from the total cultivated area in Egypt (FAO 2005). Under saline and saline-sodic soils, reduction in crop yield is associated with osmotic and specific ion effect and extent of the adverse effect is further exacerbated when saline water is used for irrigation. Therefore, under these previous conditions, biofertilizers as bioameliorators can play an important role in mitigating the adverse effects of high salt concentrations in these soils and plant production can be enhanced (Shaban et al. 2009).

The continuous application of mineral fertilizers may adversely affect soil degradation, soil chemical composition, nutrient imbalance and vegetable crop yield (Mousa and Mohamed 2009). 
To avoid the environmental pollution resulting from the over-use of mineral fertilizers, biofertilizers could be considered important candidates from sustainable agriculture point of view.

Biofertilizer can be defined as a substance contains living microorganisms, which colonizes the rhizosphere or the interior of the plant and promotes growth by increasing the supply or availability of primary nutrients to the host plant when applied to seed, plant surfaces or soil (Vessey 2003). Furthermore, biofertilizers are essential components of organic farming and play a vital role in maintaining long term soil fertility and sustainability. Moreover, biofertilizer as to replace part of the use of chemical fertilizers reduces amount and cost of chemical fertilizers and thus prevents the environment pollution from extensive application of chemical fertilizers helping in achieving sustainability of farms (Kumar et al. 2013; 2015).

The main target of this study was to evaluate the role of biofertilizers in improving green onion productivity in salt-affected soils. Moreover, studying suitable strategy of integrated nutrient with biofertilizers and different level of mineral fertilizers to reduce the amount of chemical fertilizers application.

\section{Materials and Methods}

\section{Experimental design}

This study was carried out during two successive seasons of 2014 and 2015 at the Experimental Research Farm, Sakha Horticulture Station, Kafr El-Sheikh to study the effect of mineral fertilizers and biofertilizers as well as their interactions on the growth and yield components of green onion (Allium cepa) grown under salt-affected soils. Onion seeds (cv. Giza 6) were sown in the nursery beds on the $3^{\text {rd }}$ and $5^{\text {th }}$ of October in both two seasons, respectively. After two months from sowing, the seedlings were transplanted from the nursery into the field on both sides of the ridge at a spacing of $10 \mathrm{~cm}$ for each row on $2^{\text {nd }}$ and $4^{\text {th }}$ January in both seasons respectively. Experimental treatments were randomly arranged in a randomized complete blocks design with three replicates and all treatments can be tabulated in Table 1. Onion transplants were inoculated by dipping for about 2 hours in a solution consists of biofertilizer cultures (500 $\mathrm{ml}$ of each one) and $40 \%$ (w/v, i.e. $80 \mathrm{~g}$ dissolved in $200 \mathrm{ml}$ water) sucrose solution and then took place directly in the permanent field. The rest of this solution was added to plants for the irrigated field.

Biofertilizer solution was containing $500 \mathrm{ml}$ of $\mathrm{N}_{2-}$ fixing free living bacterial cultures (Azotobacter chroococcum; $8.4 \times 10^{11} \mathrm{cfu} \mathrm{ml}^{-1}$ and Azospirillium lipoferum D178; $7.2 \times 10^{11} \mathrm{cfu} \mathrm{ml}^{-1}$ ) as well as $500 \mathrm{ml}$ of phosphate dissolving bacterial culture (Bacillus megaterium; $8.3 \times 10^{11} \mathrm{cfu} \mathrm{ml}^{-1}$ ), as well as Bacillus circulans as potassium dissolving bacterial culture $\left(9 \times 10^{11} \mathrm{cfu} \mathrm{m}^{-1}\right)$. The biofertilizer cultures were prepared by strains preserved in the Agriculture Botany Department (Microbiology Branch), Faculty of Agriculture, Benha University, Egypt. Ammonium sulphate, calcium super phosphate and potassium sulphate fertilizers were added at a rate of 240,360 and $120 \mathrm{~kg} \mathrm{ha}^{-1}$, respectively as a recommended dose. Phosphate fertilizer was added for experimental plots during soil preparation, whereas both $\mathrm{NH}_{4} \mathrm{NO}_{3}$ and $\mathrm{K}_{2} \mathrm{SO}_{4}$ fertilizers were divided into two doses, where the first and second doses added before the first and second irrigation, respectively. The preceding crop was sugar beet. Table 1:

\section{Soil and plant analyses}

Random soil samples were taken before green onion transplanting for biological and chemical analysis as described by Page et al. (1982). The experimental farm soil was clayey soil texture with $\mathrm{pH} 8.37$ and soil salinity $2.1 \mathrm{dS} \mathrm{m}^{-1}$. It is classified as a sodic soil where $\mathrm{EC}<4 \mathrm{dS} \mathrm{m}^{-1}$, SAR $>13$ and ESP $>15 \%$ (Horneck et al. 2007). The enzymes activity of dehydrogenase and alkaline phosphatase were measured using method of Schinner et al (1996) before cultivation and after harvesting in the rhizosphere.

\begin{tabular}{|c|c|}
\hline Treatments & Description \\
\hline T1 & Control (recommended dose from NPK or $100 \%$ mineral from NPK) \\
\hline $\mathrm{T} 2$ & $100 \% \mathrm{~N}$ mineral + Bio $\mathrm{PK}+1 / 3$ mineral $\mathrm{PK}$ \\
\hline $\mathrm{T} 3$ & $100 \% \mathrm{~N}$ mineral + Bio $\mathrm{PK}+2 / 3$ mineral $\mathrm{PK}$ \\
\hline $\mathrm{T} 4$ & $100 \% \mathrm{~N}$ mineral + Bio PK $+100 \%$ mineral PK \\
\hline T5 & $100 \%$ PK mineral + Bio $\mathrm{N}+1 / 3$ mineral $\mathrm{N}$ \\
\hline T6 & $100 \% \mathrm{PK}$ mineral + Bio $\mathrm{N}+2 / 3$ mineral $\mathrm{N}$ \\
\hline $\mathrm{T} 7$ & $100 \%$ PK mineral + Bio $N+100 \%$ mineral $N$ \\
\hline $\mathrm{T} 8$ & 1/3 NPK mineral + Bio $\mathrm{N}+$ Bio PK \\
\hline T9 & 2/3 NPK mineral + Bio $\mathrm{N}+$ Bio PK \\
\hline T10 & $100 \%$ NPK mineral + Bio N + Bio PK \\
\hline T11 & Bio $N+$ Bio PK \\
\hline
\end{tabular}


Before cultivation, the values of dehydrogenase and alkaline phosphatase were $9.9 \mu \mathrm{g}$ TPF (Triphenyl Formazan) $\mathrm{g}^{-1} \mathrm{dw} \mathrm{h} \mathrm{h}^{-1}$ and $4.3 \mu \mathrm{g} \rho \mathrm{NP}$ ( $\rho$-nitrophenol) $\mathrm{g}^{-1} \mathrm{~h}^{-1}$, respectively. The plot area was $10.5 \mathrm{~m}^{2}$ and the plant density recorded 40 plants per $\mathrm{m}^{2}$. At harvest, ten plants from each plot were randomly taken to evaluate vegetative growth characteristics, i.e., plant height $(\mathrm{cm})$, leaf area $\left(\mathrm{dm}^{2}\right)$ per plant number of leaves/plant, leaves fresh weight $(\mathrm{g})$ per plant, dry weight of leaves per plant, total chlorophyll content, whole plant weight $(\mathrm{g})$, bulb weight $(\mathrm{g})$, and total yield $\left(\mathrm{kg} \mathrm{m}^{2}\right)$. Leaf chlorophyll content was estimated using SPAD-502 meter (Minolta Inc., Osaka, Japan). Using hand-held chlorophyll absorbance meters, which calculates an index based on absorbance at 650 and $940 \mathrm{~nm}$ (Mielke et al. 2012). After harvest soil samples were analyzed to determine both soil acidity and salinity.

\section{Statistical analysis}

All obtained data were recorded on plot basis and statistically analyzed according to the randomized complete block design in factorial arrangement using Duncan's Multiple Range Test at $5 \%$ level to compare between treatment means as described by Gomez and Gomez (1984).

\section{Results and discussion}

\section{Soil enzymes activity}

During the two growing seasons, the effects of mineral NPK-fertilizers and NPK-biofertilizers tended to be stronger when both combined together reaching to $100 \%$. The combination of NPK- biofertilizers and mineral NPK-fertilizer (100\%; T10) recorded the highest values (Fig 1) of dehydrogenase and alkaline phosphatase activities (35.3 $\mu \mathrm{g}$ TPF $\mathrm{g}^{-1} \mathrm{dw} \mathrm{h} \mathrm{h}^{-1}$ and $20.9 \mu \mathrm{g} \rho \mathrm{NP} \mathrm{g}^{-1} \mathrm{~h}^{-1}$, respectively). From these results, it could explain that microbial inoculants need to enhance their microbial activities using mineral fertilizers, even in partial. So, it could state that using lower doses of NPK mineral fertilizers recorded significant proper values of these microbial enzymes activity which increase nutrients availability and absorption (Vessey 2003). That means the inoculation with biofertilizers led to be a difference in general between full dose of chemical fertilizer and $1 / 3$ or $2 / 3$ dose in many parameters is not significant. Moreover, the high NPK- mineral fertilizer doses can be more effective when combined with NPK- microbial inoculants comparing with the individual microbial inoculant. These results are in agreement with those obtained by (Shams et at. 2013; Abd El-Aal and Abd El-Rahman 2014).

It is well documented that, soil enzyme activity has been suggested to be an index of soil fertility, whereas soil microbial activity has been used as an accurate fertility index (Mganga et al. 2015). In general, the response of enzyme activities to different NPK-nutrient additions (i.e. stimulation, inhibition and neutral) was highly dependent on land use system as well as the background levels of available nutrients in soils. The extracellular enzymes play an important role in soil biogeochemical cycles $(\mathrm{C}, \mathrm{N}$ and $\mathrm{P})$ involved in nutrient transformation. On the other hand, it is reported that intracellular enzyme activities are

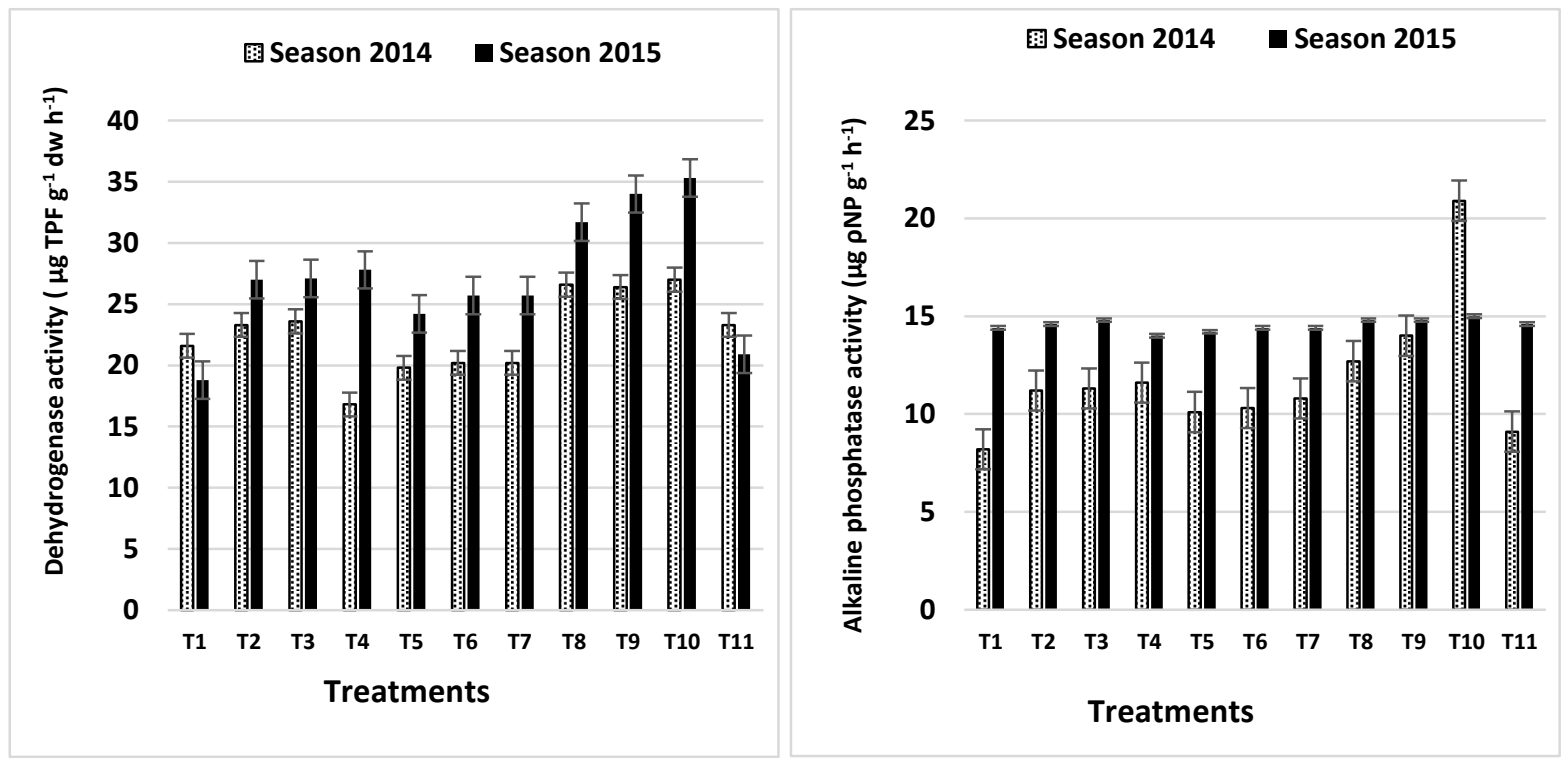

Fig 1: Effect of mineral- and biofertilizer combinations on dehydrogenase and alkaline phosphatase activity For more details about treatments: T1 to T11 see Table 1 
Table 2. Effects of different mineral- and biofertilizer combinations on some vegetative growth parameters of green onion plants

\begin{tabular}{|c|c|c|c|c|c|c|}
\hline \multirow[b]{2}{*}{ Treatments } & \multicolumn{2}{|c|}{ Plant height (cm) } & \multicolumn{2}{|c|}{ Leaf area $\left(\mathrm{dm}^{2} /\right.$ plant $)$} & \multicolumn{2}{|c|}{ No. of leaves per plant } \\
\hline & 2014 & 2015 & 2014 & 2015 & 2014 & 2015 \\
\hline $\mathrm{T} 1$ & $40.75^{a b}$ & $39.90^{\mathrm{cd}}$ & $20.35^{b c}$ & $19.52 \mathrm{de}$ & $5.80^{\mathrm{b}}$ & $5.53^{\text {bcde }}$ \\
\hline $\mathrm{T} 2$ & 38.92 cde & $36.61^{\mathrm{f}}$ & $19.41^{\text {cde }}$ & 18.97 ef & $5.63 \mathrm{bc}$ & $5.09 \mathrm{de}$ \\
\hline $\mathrm{T} 3$ & 39.58 bcd & $37.86^{\mathrm{e}}$ & $19.95^{\mathrm{cd}}$ & 19.21 ef & $5.80^{\mathrm{b}}$ & 5.35 bcde \\
\hline $\mathrm{T} 4$ & $41.63^{\mathrm{a}}$ & $40.72^{b c}$ & $21.99^{b}$ & $20.05^{\text {cde }}$ & $5.94^{a b}$ & $5.83^{a b c}$ \\
\hline T5 & 38.50 de & $36.00^{f}$ & $19.91^{\mathrm{cd}}$ & 19.07 ef & $5.44^{b c}$ & 5.37 bcde \\
\hline T6 & $40.31^{a b c}$ & $39.08 \mathrm{de}$ & $18.20^{\mathrm{de}}$ & $18.40^{\mathrm{fg}}$ & $5.63^{b c}$ & $5.20^{\text {cde }}$ \\
\hline $\mathrm{T} 7$ & $41.81^{\mathrm{a}}$ & $40.61^{b c}$ & $21.12^{b c}$ & $20.93^{c}$ & $5.73^{\mathrm{b}}$ & $5.69^{\text {abcd }}$ \\
\hline $\mathrm{T} 8$ & $41.01^{\mathrm{ab}}$ & $41.58^{a b}$ & $20.06^{\mathrm{cd}}$ & $20.30^{\mathrm{cd}}$ & $5.80^{\mathrm{b}}$ & $5.73^{\text {abcd }}$ \\
\hline T9 & $41.47^{\mathrm{a}}$ & $41.63^{a b}$ & $24.71^{\mathrm{a}}$ & $23.41^{\mathrm{b}}$ & $5.87^{a b}$ & $5.90^{\mathrm{ab}}$ \\
\hline T10 & $41.86^{\mathrm{a}}$ & $42.10^{\mathrm{a}}$ & $26.24^{\mathrm{a}}$ & $24.73^{\mathrm{a}}$ & $6.33^{\mathrm{a}}$ & $6.19^{\mathrm{a}}$ \\
\hline $\mathrm{T} 11$ & $37.80^{\mathrm{e}}$ & $35.91^{f}$ & $17.89^{\mathrm{e}}$ & $17.78^{\mathrm{g}}$ & $5.20^{\mathrm{c}}$ & $4.97^{\mathrm{e}}$ \\
\hline
\end{tabular}

Values followed by the same letters are not significantly different by LSD's test at 0.05 level 1 square decimeter $\left(\mathrm{dm}^{2}\right)=100 \mathrm{~cm}^{2}$

short-lived because they are degraded by proteases unless they are adsorbed by clays or immobilized by humic molecules (Burns and Dick 2002). Therefore, significant reductions in soil enzyme activities and soil microbial biomass under agricultural compared to natural ecosystems should be considered as indicators of soil quality and land use impacts (Mganga et al. 2015). So, both of microbial and biochemical characteristics of soil have been proposed as indicators of soil quality in natural as well as agricultural systems. This is mainly attributed to their central role in cycling of $\mathrm{C}, \mathrm{N}$ and other nutrients as well as sensitivity to change (Nannipieri et al. 2003). It is reported that, microbial community composition is sensitive to $\mathrm{N}, \mathrm{P}, \mathrm{K}$ - fertilization (Allison and Martiny 2008). Many short- and longterm trials were established primarily to study the impact of different kind of fertilizers on crop production; however, an increasing number of scientists are taking advantage of these well documented experiments to study soil microbial communities as well as soil enzyme activities under different fertilization regimes (Geisseler and Scow 2014; Shrivastava and Kumar 2015).

\section{Vegetative growth parameters}

Data presented in Table 2 show that all studied vegetative growth parameters plant height $(\mathrm{cm})$, leaf area $\left(\mathrm{dm}^{2} /\right.$ plant $)$ and number of leaves per plant were significantly influenced by different mineral and biofertilizer combination. The combination between NPK-biofertilizer combined with $100 \%$ NPK-mineral fertilizer (T10) had the highest values, i.e., 41.86 and $42.10 \mathrm{~cm}, 26.24$ and $24.73 \mathrm{dm}^{2} /$ plant, 6.33 .6 and 6.19 , respectively for first and second seasons. There is no significant differences between this treatment and NPKbiofertilizers combined with $2 / 3$ NPK-mineral fertilizer (T9) followed in most cases by the treatment using PK-biofertilizer combined with $100 \%$ NPK-mineral fertilizer (T4), N- biofertilizer combined with $100 \%$ NPK-mineral fertilizers (T7). In general, the application of NPK-biofertilizer inoculants only (T11) recorded the lowest values of these vegetative parameters of green onion.

Table 3. Effects of different mineral and biofertilizer combinations on fresh and dry weight of leaves as well as total chlorophyll content of green onion

\begin{tabular}{|c|c|c|c|c|c|c|}
\hline \multirow[b]{2}{*}{ Treatments } & \multicolumn{2}{|c|}{$\begin{array}{l}\text { Fresh weight of leaves } \\
\text { (g/plant) }\end{array}$} & \multicolumn{2}{|c|}{$\begin{array}{l}\text { Dry weight of leaves } \\
\text { (g/plant) }\end{array}$} & \multicolumn{2}{|c|}{ Total chlorophyll content (SPAD unit) } \\
\hline & 2014 & 2015 & 2014 & 2015 & 2014 & 2015 \\
\hline T1 & $11.08^{\text {bcd }}$ & $11.00^{\mathrm{c}}$ & $6.94^{\mathrm{c}}$ & $6.83^{\mathrm{bc}}$ & $63.75^{b}$ & $64.50^{\mathrm{c}}$ \\
\hline $\mathrm{T} 2$ & $10.40^{\mathrm{cd}}$ & $10.47^{\mathrm{cd}}$ & $5.91 \mathrm{de}$ & $5.84 \mathrm{de}$ & $64.77^{a b}$ & $63.60^{d}$ \\
\hline $\mathrm{T} 3$ & $10.64^{\mathrm{cd}}$ & $10.50^{\mathrm{cd}}$ & $6.37^{\mathrm{cd}}$ & $6.28^{\mathrm{cd}}$ & $64.50^{a b}$ & $64.43^{c}$ \\
\hline $\mathrm{T} 4$ & $12.27^{\mathrm{ab}}$ & $11.97 \mathrm{ab}$ & $6.84^{\mathrm{c}}$ & $6.71^{\mathrm{c}}$ & $65.50^{\mathrm{ab}}$ & $65.33^{a b}$ \\
\hline T5 & $9.90^{\mathrm{d}}$ & $9.50^{\mathrm{f}}$ & $5.49^{\mathrm{e}}$ & $5.55^{\mathrm{e}}$ & $65.90^{\mathrm{ab}}$ & $65.50^{a b}$ \\
\hline T6 & $10.41^{\mathrm{cd}}$ & 10.31 de & $7.59^{\mathrm{b}}$ & $7.30^{\mathrm{b}}$ & $64.77^{a b}$ & $64.90^{b c}$ \\
\hline $\mathrm{T} 7$ & $12.25^{\mathrm{ab}}$ & $12.10^{a b}$ & $8.55^{\mathrm{a}}$ & $8.05^{\mathrm{a}}$ & $65.53^{a b}$ & $65.60^{a b}$ \\
\hline $\mathrm{T} 8$ & $11.65^{a b c}$ & $11.60^{b}$ & $7.54^{\mathrm{b}}$ & $7.38^{\mathrm{b}}$ & $63.90^{\mathrm{ab}}$ & $65.53^{a b}$ \\
\hline T9 & $11.73^{a b c}$ & $11.80^{\mathrm{ab}}$ & $7.73^{b}$ & $8.02^{\mathrm{a}}$ & $63.60^{b}$ & $65.80^{\mathrm{a}}$ \\
\hline T10 & $12.62^{\mathrm{a}}$ & $12.40^{\mathrm{a}}$ & $8.81^{\mathrm{a}}$ & $8.49^{\mathrm{a}}$ & $66.13^{a}$ & $65.94^{\mathrm{a}}$ \\
\hline $\mathrm{T} 11$ & $10.56^{\mathrm{cd}}$ & 9.77 ef & $6.64^{c}$ & $6.52^{\mathrm{c}}$ & $60.03^{c}$ & $61.31^{\mathrm{e}}$ \\
\hline
\end{tabular}

Values followed by the same letters are not significantly different by LSD's test at 0.05 level 
Data presented in Table (3) show that fresh weight of leaves/ plant, dry weight of leaves and total chlorophyll content were significantly affected by different mineral and biofertilizer combinations. Fresh weight of leaves has the similar trend of previous vegetative parameters in Table (2).

The highest values of dry weight of leaves were obtained from $\mathrm{T} 10$ and $\mathrm{T} 7$ (the combination between NPK-biofertilizer $+100 \%$ NPK- mineral fertilizer and the combination between $\mathrm{N}$-biofertilizer $+100 \%$ NPK- mineral fertilizer, respectively), while the lowest values were obtained from $\mathrm{T} 2$ and $\mathrm{T} 5$ (PK- biofertilizer $+1 / 3$ PK mineral fertilizer $+100 \%$ $\mathrm{N}$ - mineral fertilizer and $\mathrm{N}$-biofertilizer $+1 / 3 \mathrm{~N}$ mineral fertilizer $+100 \%$ PK- mineral fertilizer, respectively). These results are agreed with results of Fawzy et al. (2012) and Shedeed et al. (2014). They confirmed that, although NPK- fertilizers play an important role of green onion plant growth and productivity and the vegetative growth of these plants as well as minerals uptake increased with increasing the level of NPK- fertilizers, biofertilizers can serve as alternative to these mineral fertilizers even in partial.

Furthermore, using biofertilizers with adding mineral and/or organic fertilizers led to improve the vegetative growth of green onion plants. These results reflect the important role of fertilization for enhancing and improvement of green onion quality and quantity. Regarding the proper combined dose of chemical and biofertilizer, it could be observed that, in general all the combined doses of treatments (particularly T10) increased the total chlorophyll content over the control (T1). Beneficial effects of bio and mineral fertilizers on increased chlorophyll content could be due to higher availability of nitrogen to the growing tissue and organs supplied by nitrogen fixing Azotobacter species (Chandrasekhar et al. 2005). Moreover, the positive effect of $\mathrm{N}$ supply on the formation of chloroplasts during leaf growth enhances chlorophyll content of leaves was observed by (Singh et al. 2014). In turn, the .chloroplast formation leads to an increase in the lipid content of leaves and chloroplast constituents such as chlorophyll and carotenoids (Mondal et al. 2015). These results reflected the essential and vital role of chlorophyll in crop production and different proper fertilizers are a limit factor in this process.

\section{Yield and its components}

Data presented in Table (4) and Fig 2 show that, yield and its components of green onion including plant weight $(\mathrm{g})$, bulb weight $(\mathrm{g})$ and total yield $\left(\mathrm{Kg} / \mathrm{m}^{2}\right)$ were significant affected by different treatments. NPK-biofertilizer combined with $100 \%$ NPK-mineral fertilizer (T10) had the highest whole plant weight, while no significant differences was observed with T4, T7 and T9. Concerning bulb weight, NPK-biofertilizer inoculants combined with $100 \%$ NPK-mineral fertilizer had the highest values while the lowest values were obtained from using NPK-microbial inoculants alone. Regarding the total yield of green onion, the highest values were recorded from the combination of NPK-microbial inoculants + of $100 \%$ NPK-mineral fertilizers (T10) but using treatment T9 (NPK-microbial inoculants + 2/3 NPK-mineral fertilizers) gave similar effect without any significant difference with T10. This increase in the yield and yield components for treatments that using combination of different mineral and biofertilizer may be a result of increasing vegetative growth parameters of green onion for same treatments (Tables 2 and 3),

Table 4. Effects of different mineral and biofertilizer combinations on Whole plant weight and Bulb weight of green onion

\begin{tabular}{|c|c|c|c|c|}
\hline \multirow[b]{2}{*}{ Treatments } & \multicolumn{2}{|c|}{ Plant weight (g) } & \multicolumn{2}{|c|}{ Bulb weight (g) } \\
\hline & 2014 & 2015 & 2014 & 2015 \\
\hline T1 & $33.39^{\mathrm{cd}}$ & $33.50^{\mathrm{cd}}$ & $21.96^{\mathrm{cd}}$ & $21.63^{\mathrm{e}}$ \\
\hline $\mathrm{T} 2$ & $31.97^{\mathrm{d}}$ & $31.40^{\mathrm{e}}$ & 20.32 de & $19.83^{f}$ \\
\hline $\mathrm{T} 3$ & $32.49^{\mathrm{d}}$ & $32.03 \mathrm{de}$ & $21.46^{\mathrm{cd}}$ & $21.07^{\mathrm{e}}$ \\
\hline $\mathrm{T} 4$ & $35.46^{\mathrm{abc}}$ & $34.93 \mathrm{bc}$ & $22.67^{b c}$ & $22.07 \mathrm{de}$ \\
\hline T5 & $29.07^{\mathrm{e}}$ & $28.10^{f}$ & $18.39^{\mathrm{e}}$ & $18.13^{\mathrm{g}}$ \\
\hline T6 & $33.82 \mathrm{bcd}$ & $33.50^{\mathrm{cd}}$ & $21.94^{\mathrm{cd}}$ & $21.50^{\mathrm{e}}$ \\
\hline $\mathrm{T} 7$ & $36.21^{\mathrm{ab}}$ & $35.97^{\mathrm{ab}}$ & $24.51^{\mathrm{ab}}$ & $23.94^{b}$ \\
\hline $\mathrm{T} 8$ & $33.58^{\mathrm{bcd}}$ & $33.43^{\mathrm{cd}}$ & $22.71^{b c}$ & $22.77^{\mathrm{cd}}$ \\
\hline T9 & $35.34^{a b c}$ & $35.40^{a b}$ & $23.25^{b c}$ & $23.35^{b c}$ \\
\hline T10 & $36.99^{\mathrm{a}}$ & $36.80^{\mathrm{a}}$ & $26.32^{a}$ & $25.91^{\mathrm{a}}$ \\
\hline $\mathrm{T} 11$ & $31.36^{\mathrm{de}}$ & $31.43^{\mathrm{e}}$ & $19.25^{\mathrm{e}}$ & $18.72^{\mathrm{g}}$ \\
\hline
\end{tabular}

Values followed by the same letters are not significantly different by LSD's test at 0.05 level 


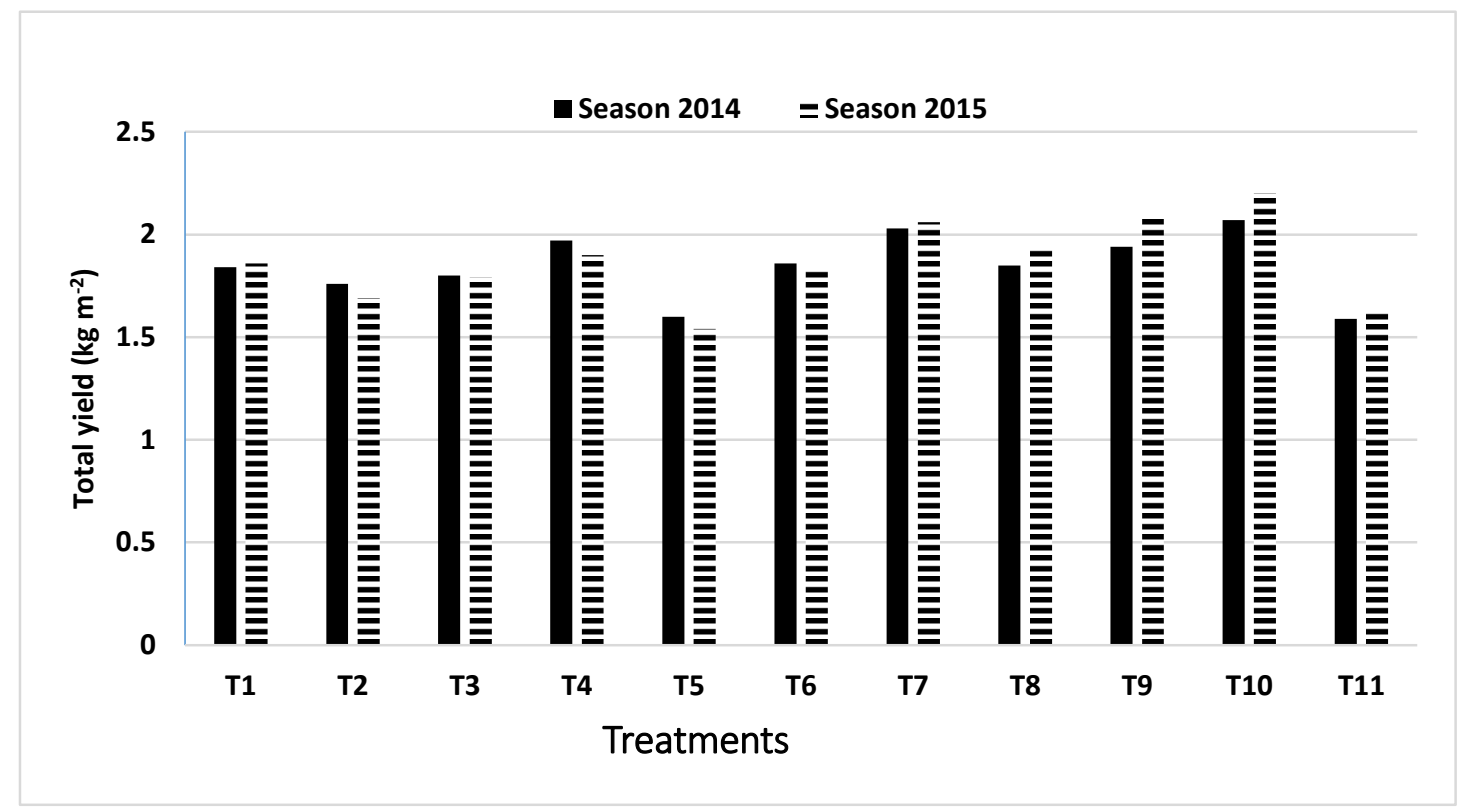

Fig2: Effects of different mineral and biofertilizer combinations on total yield of green onion

and a result of the combined favorable effects of mineral and biofertilizer. Application of biofertilizer combined with chemical fertilizer is an important approach to maintain and improve the soil fertility, increasing fertilizer use efficiency and improving crop productivity ( $\mathrm{Xu}$ et al. 2008). The role of biofertilization strains in production of phytohormones and/or improving the availability and acquisition of nutrients or by both, may explain the encouraged growth of inoculated plants with nonsymbiotic $\mathrm{N}_{2}$-fixing bacteria (Barakat and $\mathrm{Gabr}$ 1998). Furthermore, Azotobacter and Azospirillium could produce indole acetic acid and cytokinins which increased the surface area per unit of root length and were responsible for root hair branching with an eventual increase in acquisition of nutrients from the soil (Jain and Patriquin 1985). The data revealed that biofertilizer application significantly stimulated most of the studied attributes. It could be concluded that, about $33 \%$ reduced dose of chemical fertilizer and its combination with biofertilizers (T9) was accepted for most of the parameters studied as compared to the control. Considering the effects of different fertilization or nutrient sources on the chlorophyll content, there were significant influences of these nutrient sources on the chlorophyll (Amujoyegbe et al. 2007). To study the effect of reduced dose of chemical fertilizer and its combination with biofertilizer on crop productivity and biochemical traits, many investigations carried out on onion (Shedeed et al. 2014; Mahmoud et al.
2015) as well as distinguished reviews such as Mohammadi and Sohrabi (2012).

\section{Effect of NPK-biofertilizers and NPK-mineral fertilizers on Soil salinity}

After harvest soil samples were analyzed to determine effects of combined NPK-biofertilizers and NPK-mineral fertilizers on both soil acidity and salinity. Data in Table 5 observed that, increasing the NPK-mineral fertilizer level led to increase the soil salinity level, whereas the opposite can be observed regarding NPK-biofertilizers. It is well documented that, onion is sensitive or moderately sensitive crop to soil salinity, primarily at germination stages as well as emergence. Once plants are established, higher levels of soil salinity can be tolerated. About $50 \%$ reduction in yield may occur when the soil salinity level reaches to $4-5 \mathrm{dS} \mathrm{m}^{-1}$ (Smith et al. 2011). It could be distinguished from these results the ameliorative role of NPK-biofertilizer for green onion production under stressed soils (salt-affected soils) as well as its role in maximizing beneficial of high dose of NPK- mineral fertilizers At higher application rates, short- and long-term effects on soil $\mathrm{pH}$ may also be more pronounced in agricultural systems as well as soil microbial community (Geisseler and Scow 2014). Although, ammonium is the preferred $\mathrm{N}$ - source for most bacteria and fungi (Marzluf 1997). Urea and ammonium fertilizers can inhibit soil microorganisms due to toxicity of ammonia when applied at high rates, increases in $\mathrm{pH}$

Table 5: Effect of NPK-mineral- and biofertilizer combinations on soil $\mathrm{pH}$ and salinity (EC)

\begin{tabular}{|c|c|c|c|c|c|c|c|c|c|c|c|}
\hline Items & $\mathrm{T} 1$ & $\mathrm{~T} 2$ & T3 & $\mathrm{T} 4$ & T5 & T6 & $\mathrm{T} 7$ & $\mathrm{~T} 8$ & T9 & T10 & T11 \\
\hline Soil pH & 8.37 & 8.38 & 8.34 & 8.37 & 8.28 & 8.21 & 8.33 & 8.22 & 8.28 & 8.17 & 8.35 \\
\hline Soil EC* & 1.98 & 2.41 & 2.61 & 2.26 & 3.90 & 2.04 & 2.68 & 2.31 & 2.53 & 2.76 & 1.82 \\
\hline
\end{tabular}

* Soil EC $\left(\mathrm{dS} \mathrm{m}^{-1}\right)$ in paste, whereas soil $\mathrm{pH}$ in $1: 5$ extract 
and increases in ionic strength (Omar and Ismail 1999; Geisseler and Scow 2014). Concerning the values of soil $\mathrm{pH}$ in treatments $\mathrm{T} 4, \mathrm{~T} 7$ and T10 (8.41, 8.33 and 8.17 , respectively in Table 5 , it could confirm the ameliorative role of NPK-biofertilizers in decreasing soil $\mathrm{pH}$ in the presence of recommended dose of NPK-mineral fertilizers under salt-affected soils in green onion production.

It could be concluded that soil microbial inoculants either alone or in combination with mineral or organic fertilizers, could be utilized for increasing crop productivity and maintaining the fertility of soils without threatening the environment. Therefore, beneficial soil microbes should be further studied and exploited for the development of sustainable agriculture (Altomare and Tringovska 2011). It is reported that, microbial inoculants Azotobacter chroococcum and Azospirillium lipoferum can be recommended for onion crop which saving fertilizer ranging from 20 to $40 \mathrm{~kg} \mathrm{~N}$ (Bhattacharjee and Dey 2014). On the other hand, an improved soil salinity and tolerance of different crop plants by using biofertilizers in combination with mineral fertilizers was investigated in several studies. It is reported that biofertilizers alleviated adverse effects of high levels of soil salinity and plants accumulated more polyamines than those, which do not receive biofertilizers, particularly at high soil salinity levels as well as influencing the plant $\mathrm{K}$ content (Mohamed et al. 2007).

\section{Conclusion}

Based on the obtained data, it could be concluded that NPK-biofertilizers including nitrogen-fixing bacteria (Azotobacter chroococum and Azospirillium lipoferum), phosphate dissolving bacteria (Bacillus megaterium) as well as potassium dissolving bacteria (Bacillus circulans) could be used for green onion production under salt-affected soils. Therefore, it could use only the $2 / 3$ amount from NPK-mineral fertilizers combined with NPKbiofertilizers and of course saving 1/3 the amount of mineral fertilizers to obtain proper yield. Similar trend was observed for both soil enzyme activities. The proper management of soil-affected soils for avoiding its salinity or sodicity hazard can be performed via using the suitable combination from mineral and biofertilizers.

\section{References}

Abd El-Aal, M. and H. M. A. Abd El-Rahman (2014). Impact of PGPR and inorganic fertilization on growth and productivity of sweet ananas melon. International Journal of Agricultural Science and Research (IJASR), 4(3): 11-26

Allison, S. D. and J. B. H. Martiny (2008). Resistance, resilience, and redundancy in microbial communities. Proceedings of the National Academy of Sciences of the USA 105, 11512-11519.

Altomare, C. and I. Tringovska (2011). Beneficial soil microorganisms, an ecological alternative for soil fertility management. In: E. Lichtfouse (ed.), Genetics, Biofuels and Local Farming Systems, Sustainable Agriculture Reviews 7, pp: 161 - 214. DOI 10.1007/978-94-007-15219 6, Springer Science + Business Media B.V.

Amer, M.M. and H. R. El-Ramady (2015). Alleviation Soil Salinity and Sodicity Hazard using some bio-chemical Amendments for Production of canola (Brassica napus L.) in North Delta Region J. Soil Sci. and Agric. Eng. Mansoura Univ. (in press).

Amujoyegbe, B. J., J. T. Opabode and A. Olayinka (2007). Effect of organic and inorganic fertilizer on yield and chlorophyll content of maize (Zea mays L.) and sorghum Sorghum bicolour (L.) Moench). African Journal of Biotechnology 6 (16): 1869-1873. ISSN 16845315

Baliyan S. P. (2014). Evaluation of Onion Varieties for Productivity Performance in Botswana. World Journal of Agricultural Research, 2 (3): 129-135. DOI:10.12691/wjar-2-3-8

Baliyan, S. P. and P. S. Baliyan (2013). Comparative Profitability of onions harvested as green and dry (mature) in Botswana. Int. J. Agril. Res. Innov. \& Tech. 3 (1): 73-77. ISSN: 2224-0616

Barakat, M. A. and S. M. Gabr (1998). Effect of different biofertilizer types and nitrogen fertilizer levels on tomato plants. Alex. J. Agric. Res., Alex. Univ., 43: 149-160.

Bhattacharjee, R. and U. Dey (2014). Biofertilizer, a way towards organic agriculture: A review. Afr. J. Microbiol. Res. 8 (24): 2332-2343. DOI: 10.5897/AJMR2013.6374

Brewster, J. L. (2008). Onions and other vegetable alliums. $2^{\text {nd }}$ ed. CABI International

Burns, R. G. and R. P. Dick (2002). Enzymes in the environment-activity, ecology, and application. Marcel Dekker, Inc.

Chandrasekhar, B.R., G. Ambrose and N. Jayabalan (2005). Influence of biofertilizer and nitrogen source level on the growth and yield of Echinochloa frumentacea (Roxb.) Link. J. Agric. Technol. 1: 223-234.

El Sheikha A. F. and D. Montet (2015). Fermented fish and fish products: snapshots on culture and Health. In: Ray, R. C. and D. Montet (Eds.) Microorganisms and fermentation of traditional foods. Food Biology Series. P: 187 - 222, CRC Press Taylor \& Francis Group, FL, Taylor \& Francis Group, LLC

FAO (2005). Integrated management for sustainable use of salt-affected soils. (Eds. A. Mashali, D.L. Suarez, H. Nabhan, R. Rabindra). FAO Soils Bulletin, Rome. 
Fawzy, Z. F., M. M. Abou El-magd, Y. Li, O. Zhu and A. M. Hoda (2012). Influence of foliar application by EM "Effective Microorganisms", amino acids and yeast on growth, yield and quality of two cultivars of onion plants under newly reclaimed soil. Journal of Agricultural Science 4 (11): 26 - 39. ISSN 1916-9752

Geisseler, D. and K. M. Scow (2014). Long-term effects of mineral fertilizers on soil microorganisms: A review. Soil Biology \& Biochemistry 75: 54-63. http://dx.doi.org/10.1016/j.soilbio.2014.03.023

Gomez, K. A. and A. A. Gomez (1984). Statistical procedures for agricultural research, $2^{\text {nd }}$ ed. John Wiley and Sons, New York, 680 pp.

Horneck, D. A., J. W. Ellsworth, B. G. Hopkins, D. M. Sullivan and R. G. Stevens (2007). Managing Salt-affected Soils for Crop Production. PNW 601-E November 2007, A Pacific Northwest Extension publication Oregon State University • University of Idaho • Washington State University

Hussein; M. A. M., M. H. A. Hassan, A. D. A. Allam and K. A. M. Abo-Elyousr (2007). Management of Stemphylium blight of onion by using biological agents and resistance inducers. Egypt. J. Phytopathol. 35 (1): 49-60.

Jain, D. K. and D. G. Patriquin (1985). Characterization of a substance produced by Azospirillum which causes branching of wheat root hairs. Can. J. Microbiol., 31: 206-210.

Kumar, A., J. Prakash and N. K. Arora (2015). Biofertilizers: an alternative sources of chemical fertilizer for sustainable crops in $21^{\text {st }}$ century. Pp: 28 - 31. Microbiology World Issue 10 Mar - Apr 2015, ISSN 2350 - 8774

Kumar, K., U. N. Shukla, D. Kumar, A. K. Pant and S. K. Prasad (2013). Bio-Fertilizers for organic agriculture. Popular Kheti 1 (4): 91 - 96.

Mahmoud, E., E. El-Gizawy and L. Geries (2015). Effect of compost extract, $\mathrm{N}_{2}$-fixing bacteria and nitrogen levels applications on soil properties and onion crop, Archives of Agronomy and Soil Science, 61 (2): 185-201. DOI: $10.1080 / 03650340.2014 .928409$

Malhi, S.S., J.T. Harapiak, M. Nyborg and K.S. Gill (2000). Effects of long-term applications of various nitrogen sources on chemical soil properties and composition of brome grass hay. Journal of Plant Nutrition 23: 903-912.

Marzluf, G.A. (1997). Genetic regulation of nitrogen metabolism in the fungi. Microbiology \& Molecular Biology Reviews 61: 17-32.

Mganga, K. Z., B. S. Razavi and Y. Kuzyakov (2015). Microbial and enzymes response to nutrient additions in soils of Mt. Kilimanjaro region depending on land use. European Journal of Soil Biology 69: 33-40. http://dx.doi.org/10.1016/j.ejsobi.2015.05.001
Mielke, M.S., B. Schaffer, and A. C. Schilling (2012). Evaluation of reflectance spectroscopy indices for estimation of chlorophyll content in leaves of a tropical tree species. PHOTOSYNTHETICA 50 (3): 343-352. DOI: 10.1007/s11099-012-0038-2

Mohamed A. A., B. Eichler-Löbermann and E. Schnug (2007). Response of crops to salinity under Egyptian conditions: a review. Landbauforschung Völkenrode 2 / 2007 (57):119-125

Mohammadi, K. and Y. Sohrabi (2012). Bacterial biofertilizers for sustainable crop production: a review. Journal of Agricultural and Biological Science 7 (5): 307 - 316.

Mondal, T., J. K. Datta and N. K. Mondal (2015). Chemical fertilizer in conjunction with biofertilizer and vermicompost induced changes in morpho-physiological and biochemical traits of mustard crop. Journal of the Saudi Society of Agricultural Sciences, http://dx.doi.org/10.1016/j.jssas.2015.05.001

Mousa M. A. A. and M. F. Mohamed (2009). Enhanced yield and quality of onion (Allium cepa L. cv Giza 6) produced using organic fertilization. Ass. Univ. Bull. Environ. Res. 12 (1): $9-19$.

Nannipieri, P., J. Ascher, M. T. Ceccherini, L. Landi, G. Pietramellara and G. Renella (2003). Microbial diversity and soil functions. European Journal of Soil Science 54 (4): 655670.

Omar, S.A. and M. Ismail (1999). Microbial populations, ammonification and nitrification in soil treated with urea and inorganic salts. Folia Microbiologica 44: 205-212.

Page, A. L. R., H. Miller and D. R. Keeney (1982). Methods of Soil Analysis. Part 2: Chemical and Microbiological Properties. $2^{\text {nd }}$ Edition, Agronomy Monograph, No. 9, ASA, CSSA, and SSSA, Madison.

Pérez-Gregorio, M. R., J. Regueiro, J. SimalGandara, A. S. Rodrigues and D. P. Almeida (2014). Increasing the added-value of onions as a source of antioxidant flavonoids: A critical review. Crit. Rev. Food Sci. Nutr., 54(8):10501062.

Qadir, M., S. Schubert, A. D. Noble, M. Saqib and M. Saifullah (2006). Amelioration strategies for salinity-induced land degradation. CAB Reviews: Perspectives in Agriculture, Veterinary Science, Nutrition and Natural Resources $\quad .1: 069 . \quad$ DOI: 10.1079/PAVSNNR20061069.

Schinner, F., R. Oehlinger, E. Kandeler, R. Margesin (1996). Methods in Soil Biology. Springer Lab Manuals, Part I. pp: 213-241.

Shaban, Kh. A., A. A. Mahmoud, A. Mansour and M. G. Abd El-Kader (2009). Biofertilizer and organic manure affects rice productivity in 
newly reclaimed saline soil. Dynamic Soil, Dynamic Plant, 3 (1): 55 - 60.

Shams, A.S.; H.M. Abdel-Rahman and H.R. ElRamady (2013). Evaluation of Integrated Nutrient Management Practices for Lettuce Production under Drip Irrigation System. Journal of Applied Sciences Research, 9(3): 2223-2231.

Shedeed, S. I., S. A. A. EL-Sayed and D. M. Abo Bash (2014). Effectiveness of bio-fertilizers with organic matter on the growth, yield and nutrient content of Onion (Allium cepa L.) plants. European International Journal of Science and Technology 3 (9): 115 - 122. ISSN: 2304-9693

Shrivastava, P. and R. Kumar (2015). Soil salinity: A serious environmental issue and plant growth promoting bacteria as one of the tools for its alleviation. Saudi Journal of Biological Sciences 22: 123-131.
Singh, M., M. M. A. Khan and M. Naeem (2014). Effect of nitrogen on growth, nutrient assimilation, essential oil content, yield and quality attributes in Zingiber officinale Rosc. J. Saudi Soc. Agric. Sci. http://dx.doi.org/10.1016/j.jssas.2014.11.002.

Smith, R., M. Cahn, M. Cantwell, S. Koine, E. Natwick, and E. Takele (2011). Green onion production in California. Vegetable Production Ser. University of California, Agriculture and Natural Resources.

Vessey J. K. (2003). Plant growth promoting rhizobacteria as biofertilizers. Plant and Soil 255: 571-586.

Xu, M., D. Li, J. Li, D.Q.Y. Kazuyuki, Y. Hosen (2008). Effect of organic manure application with chemical fertilizers on nutrient absorption and yield of rice in Hunan southern china. China J. Agric. Sci., 7(10): 1245-1252. 


\section{هل يمكن للتسميد الحيوى تحسين إنتاجية البصل الأخضر تحت الاجهاد الملحي؟}

$$
\begin{aligned}
& \text { منال عبداله ، هاني عبد الرحمن وحسن الرمادي3 } \\
& \text { (1) قسم الخضروات خلطية التلقيح - محطة بحوث البساتين بسخا - مركز البحوث الزراعية - مصر . }
\end{aligned}
$$

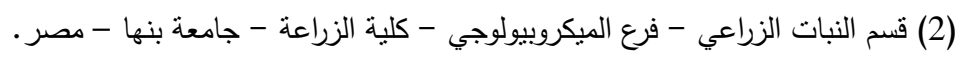

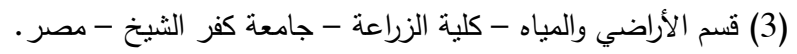

في الدراسة الحالية، أجريت تجربتين متتاليتين خلال موسمي 2014 و 2015 في مزرعة محطة بحوث البساتين بسخا ، كفر الثيخ. وقد أثتثلت التجربة علي أحد عشر معاملة بين الاسمدة الحيوية للنيتروجين والبوتاسيوم والفوسفور(NPK-ميكروبي) مع ثلث او تلثي او الجرعة الكاملة الموصي بها من الاسمدة المعنية للنيتروجين والبوتاسيوم والفوسفور لدراسة تأثثر ذلك على جودة وإنتاجية البصل الأخضر المنزرع في التربة المنأثرة بالملوحة. وكذلك على الأنشطة الإنزيمية لميكروبات التربة. بشكل عام فان أعلى القيم لانزيمات الديهيدروجينيز و الفوسفاتيز القلوية، كانت

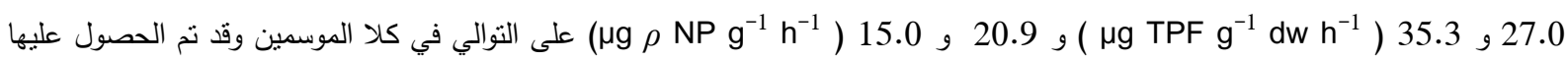
باستخدام الجمع بين الجرعة الكاملة من الأسمدة المعنية (النيتروجينية والبوتاسية والفوسفاتية) و الأسمدة الحيوية ( NPK-الميكروبي) .وفيما يتعلق بقياسات النمو الخضري والمحصول الكلي، كان لاستخدام الأسمدة الحيوية مع الجرعة الكاملة من الأسمدة المعدنية أعلى القيم. هذا ولم تكن هناك فروق معنوية في معظم القياسات بين معاملات الجرعة الكاملة من الاسمدة المعنية والاسمدة الحيوية المختلفة ، مقارنة بمعاملة 3/2 الجرعة من الاسمدة المعنية مع الاسمدة الحيوية. وقد انخفض محتوى الكلوروفيل في النباتات المعاملة باللقحات الحيوية وحدها .وعلاوة على ذلك، فقد أدى استخدام الأسددة الحيوية الي تقليل ملوحة التربة نسبيا. ونتير ننائج هذه الدراسة الي، إنه يجب أن يتم استبدال الاسمدة المعنية بالأسمدة الحيوية ، ولو جزئيا، لانتاج غذاء نظيف كما ينبغي استخدام مثل هذا البرنامج المتكامل لإدارة العناصر الغذائية تحت التربة المتأثرة بالملوحة. 